\title{
Thiophenes on Mars: Biotic or Abiotic Origin?
}

\author{
Jacob Heinz ${ }^{1}$ and Dirk Schulze-Makuch ${ }^{1-4}$
}

\begin{abstract}
The question whether organic compounds occur on Mars remained unanswered for decades. However, the recent discovery of various classes of organic matter in martian sediments by the Curiosity rover seems to strongly suggest that indigenous organic compounds exist on Mars. One intriguing group of detected organic compounds were thiophenes, which typically occur on Earth in kerogen, coal, and crude oil as well as in stromatolites and microfossils. Here we provide a brief synopsis of conceivable pathways for the generation and degradation of thiophenes on Mars. We show that the origin of thiophene derivatives can either be biotic or abiotic, for example, through sulfur incorporation in organic matter during early diagenesis. The potential of thiophenes to represent martian biomarkers is discussed as well as a correlation between abundances of thiophenes and sulfate-bearing minerals. Finally, this study provides suggestions for future investigations on Mars and in Earth-based laboratories to answer the question whether the martian thiophenes are of biological origin. Key Words: MarsOrganic compounds-Thiophenes-Biotic-Abiotic-Curiosity-Biomarker. Astrobiology 20, 552-561.
\end{abstract}

\section{Introduction}

T HE FIRST DETECTION of organic compounds on Mars was done by gas chromatography-mass spectrometry (GC-MS) on the Viking landers, which revealed the presence of chloromethane and dichloromethane. At that time, this detection was interpreted as terrestrial contamination, but it is now realized that it derived most likely from the reaction of indigenous martian organic compounds with perchlorate (Navarro-González et al., 2010). A reanalysis of Viking mission data was also consistent with the detection of aromatic organic compounds such as chlorobenzene (Guzman et al., 2018). Recently, chlorobenzene (150-300 ppb) was also detected by the Curiosity rover in the Sheepbed mudstone of Gale Crater (Freissinet et al., 2015). In addition, $\mathrm{C}_{2}$ to $\mathrm{C}_{4}$ dichloroalkanes (up to $70 \mathrm{ppb}$ ) have been found, but it could not be completely ruled out that these compounds resulted from instrument background sources (Freissinet et al., 2015).

A more convincing discovery of the existence of indigenous organic compounds on Mars was the detections reported by Eigenbrode et al. (2018) in lacustrine mudstone of the Murray formation in Gale Crater. They found several aliphatic, aromatic, and thiophenic compounds at nanomolar levels through evolved gas analysis (EGA) and pyrolysis-GC-MS. Many more organic compounds are likely present as the methodology of pyrolysis-GC-MS was recently been shown to inhibit the detection of organic compounds when perchlorates and oxyanion salts are present (Montgomery et al., 2019).

Nevertheless, the organic matter detected by Eigenbrode et al. (2018) contained 5\% carbon as organic sulfur molecules. Interestingly, the sulfur-containing molecules detected on Mars include thiophene and some of its derivatives (2-methylthiophene, 3-methylthiophene, and presumably benzothiophene) as well as smaller fragments (methanethiol, dimethyl sulfide, carbonyl sulfide, carbon disulfide, hydrogen sulfide, and sulfur dioxide) (Eigenbrode et al., 2018). Since sulfur compounds are essential for life and thiophenes play an important role in the sulfur cycle on Earth (Kertesz, 2000), we present here a brief summary of conceivable biotic and abiotic production and degradation pathways of martian thiophenes and their potential in representing biomarkers.

\section{Thiophenes on Earth}

\subsection{Thiophenes-formation in natural environments and significance as biomarkers}

Thiophenes are aromatic five-membered rings containing four carbon atoms and one sulfur atom. They occur naturally in kerogens, bitumen, coals, crude oil (petroleum), and sediments at concentrations up to $\sim 10 \mathrm{wt} \%$ (Table 1).

In these environments, the thiophenes are thought to be produced abiotically during diagenesis where inorganic

\footnotetext{
${ }^{1}$ Center for Astronomy and Astrophysics (ZAA), Astrobiology Research Group, Technische Universität Berlin, Berlin, Germany.

${ }^{2}$ German Research Centre for Geosciences (GFZ), Section Geomicrobiology, Potsdam, Germany.

${ }^{3}$ Department of Experimental Limnology, Leibniz-Institute of Freshwater Ecology and Inland Fisheries (IGB), Stechlin, Germany.

${ }^{4}$ School of the Environment, Washington State University, Pullman, WA, USA.
} 
Table 1. Examples of Total Sulfur and Thiophenic Sulfur Contents in Various Sulfur-Rich Environments

\begin{tabular}{|c|c|c|c|}
\hline Environment (specific sample denotation) & Total S (wt \%) & Thiophenic S [mol\%] ${ }^{\mathrm{a}}$ & References \\
\hline Kerogen, Woodford Shale $\left(R_{\mathrm{O}} 0.55 \%\right)$ & 3.5 & 78 & Craddock et al. (2018) \\
\hline Kerogen, Jordan (Muwaqqar, IIS) & $11.1^{\mathrm{b}}$ & 44 & Pomerantz et al. (2014) \\
\hline Bitumen, Jordan (Muwaqqar, IIS) & $13.3^{\mathrm{b}}$ & 41 & Pomerantz et al. (2014) \\
\hline Petroleum, Utah, USA (Rozel Point) & 14.0 & 60 & Waldo et al. (1991) \\
\hline Adriatic petroleum (Fillentino) & 11.5 & 83 & Waldo et al. (1991) \\
\hline Raša coal, Croatia & 11.4 & 70 & Sinninghe Damsté et al. (1999) \\
\hline South China Sea sediments & n.d. & $11-66 \mathrm{ng} / \mathrm{g}^{\mathrm{c}}$ & Yang et al. (1998) \\
\hline Microfossils & n.d. & $10-300 \mathrm{ppm}$ & Lemelle et al. (2008) \\
\hline Fossil stromatolites & n.d. & n.d. & Lepot et al. (2009) \\
\hline
\end{tabular}

${ }^{\mathrm{a}}$ Referred to total sulfur, unless otherwise stated.

${ }^{\mathrm{b}}$ Only organic sulfur.

${ }^{c}$ Range of masses of dibenzothiophene in $1 \mathrm{~g}$ marine sediment soils.

n.d., not determined.

sulfur nucleophiles such as sulfides (e.g., $\left.\mathrm{H}_{2} \mathrm{~S}\right)$ react with organic matter at elevated temperatures (Kohnen et al., 1991; Krein and Aizenshtat, 1994). However, the parent substances of these reactions can indeed be biological in origin. The production of sulfides by sulfatereducing bacteria is driving the sulfurization of organic matter during diagenesis (Kenig and Huc, 1990), whereas the organic matter itself includes biomolecules such as lipids or terpenoids (Simoneit, 2005).

One proposed mechanism of the formation of isoprenoid thiophenes detected in many sediments is the incorporation of sulfur into chlorophyll-derived phytol or bacteriochlorophyllderived phytenes to yield polysulfides followed by the thermal conversion into thiophenes (Brassell et al., 1986; Krein and Aizenshtat, 1994). It even has been argued that the ratios of different isoprenoid thiophenes can be used to distinguish between hypersaline and nonhypersaline paleoenvironments depending on the occurrence of certain bacteriochlorophylls in these environments (Leeuw and Sinninghe Damsté, 1990).

Thus, thiophenes can represent at least secondary biomarkers. In general, due to the formation of intermolecular sulfur bonding (polymerization), sulfur-rich biomarkers are more stable and preservable than biomarkers with a low sulfur/carbon ratio and are, therefore, prolonging the lifetime of these biomarkers in the geological record (Sinninghe Damsté et al., 1989; Lemelle et al., 2008). It has been shown that even at relatively high levels of thermal maturity, alkylthiophenes are stable thermal degradation products wherein the positions of the thiophene moiety coincides with the original positions of the functional groups of their precursors (Koopmans et al., 1995, 1996). This implies that alkylthiophenes are useful biomarkers because the information regarding the original positions of functionalities in the precursor molecules is retained (Koopmans et al., 1995).

Indeed, thiophenes were detected in the cell wall of 700 800 Ma-old Neoproterozoic microfossils (Lemelle et al., 2008) as well as in 2.72 Ga-old fossil stromatolites (Lepot et al., 2009). Although it remained unclear whether the thiophenic compounds are of endogenous origin or were produced through diagenesis of the microfossils, Lemelle et al. noted that the low sulfur content (10-300 ppm) within the cell-like structures points toward an endogenous origin because these quantities are more comparable with sulfur contents in living microorganisms (e.g., $4000 \mathrm{ppm}$ for single marine cyanobacterial cells) than with the sulfur content in kerogens, which is usually at a percentage level (Table 1).

The thiophene synthesis during diagenesis is influenced by at least six major aspects:

(1) Thermal maturation: with increasing maturity (higher temperatures and pressures during diagenesis and early catagenesis), the total sulfur content of the environment (kerogen, oil, or coal) decreases, for example, by outgassing of $\mathrm{H}_{2} \mathrm{~S}$. Nevertheless, the relative abundance of thiophenic compounds (especially dibenzothiophenes) increases due to their enhanced thermal stability (Orr and Sinninghe Damsté, 1990).

(2) Content of total sulfur and organic carbon: the thiophene concentration in sediments and coals correlates with the content of organic carbon and total sulfur (Yang et al., 1998; Wawrzynkiewicz and Sablik, 2002).

(3) Clay content: sediments having higher clay content favor accumulation of dibenzothiophene (Yang et al., 1998), although, in general, the sulfur content in clayrich sediments is low (see Point 4).

(4) Carbonate content: carbonate deposits contain larger amounts of organic sulfur compounds (including thiophenes) than clay-rich clastic environments (Kenig and Huc, 1990). The reason for this observation might be that clay-rich clastic deposits contain more iron than carbonate muds (see Point 5) (Krein, 1993).

(5) Iron concentration: iron competes successfully with organic matter as a sink for sulfur by the formation of pyrite (Berner et al., 1985). Thus, thiophene synthesis in iron-rich environments is limited to a certain degree.

(6) Sulfate-reducing bacteria: when the microbial $\mathrm{H}_{2} \mathrm{~S}$ production exceeds the formation of pyrite, the rate of sulfur incorporation into organic matter during early diagenesis is increased (Kenig and Huc, 1990).

\subsection{Biosynthesis of thiophenes}

Besides the formation of thiophenic compounds as secondary biomarkers during early diagenesis, only a few examples of direct biosynthesis of thiophenes are described. Caldariellaquinone (CQ) is a benzo[b]thiophen-4,7-quinone (Fig. 1A) that first has been isolated from the extremely 
A<smiles>CCCC(C)C(C)CCC(C)C</smiles>

B

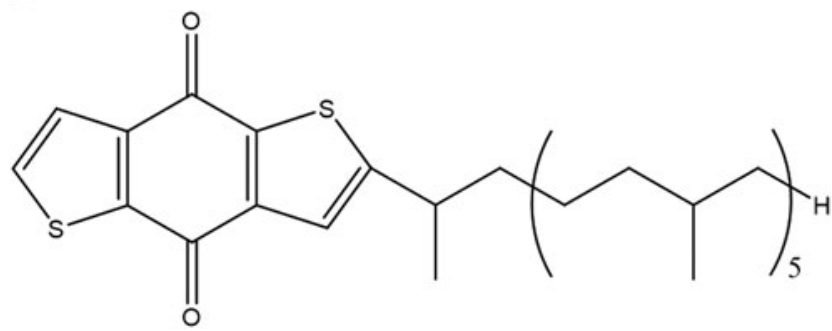

FIG. 1. Chemical structures of Caldariellaquinone (A) and benzodithiopheno-quinone (B).

thermo- and acidophilic archaeon Caldariella acidophila (de Rosa et al., 1975, 1977). Today, it is known that CQ is the major component of the quinone fraction in all known Sulfolobus spp. (Zhou and White, 1989). In Sulfolobus solfataricus, a CQ analog — benzodithiopheno-quinone (BDTQ) has been discovered that contains even two thiophene rings (Fig. 1B) (Lanzotti et al., 1986).

CQ and BDTQ might fulfill respiratory functions like other quinones, for example, ubiquinone, and tyrosine might serve as a source material for their biosynthesis (Zhou and White, 1989). Thus, it can be hypothesized that the thiophenes found in natural environments (Table 1) could also be-at least in part-the metabolic fossils of archaebacterial metabolism (Juhl and Clark, 1990). It has been suggested that under severe reducing conditions of hypersaline sediments, CQ could degrade into smaller fragments, including thiophenes and benzothiophenes as detected on Mars (Eigenbrode et al., 2018), which could serve as biomarkers (Wang and Fu, 1997).

In addition, the biosynthesis of thiophene and some derivatives has been described for bacteria associated with fruiting bodies of the white truffle Tuber borchii (Splivallo et al., 2015). The truffle bacteria community was dominated by $\alpha$ - and $\beta$-Proteobacteria, whereas $\gamma$-Proteobacteria and Bacteroidetes were detected at much lower quantities. Interestingly, all of these phyla/classes -independent of their isolation source (truffle or other sources such as soil) - were able to produce thiophenes (Splivallo et al., 2015). Together with the biosynthesis of CQ and BDTQ, this indicates that microbial thiophene production might be a widespread metabolic pathway.

\subsection{Biodegradation of thiophenes}

Thiophenes can be degraded microbially by either sulfatereducing or sulfur-oxidizing bacteria. One potential metabolic pathway for microbial sulfur oxidation is the formation of a sulfone followed by its degradation to sulfite $\left(\mathrm{SO}_{3}{ }^{2-}\right)$ and an alcohol (Fig. 2A). This pathway has been shown for various bacterial strains degrading, for example, dibenzothiophene (Kertesz, 2000; Gogoi and Bezbaruah, 2002). The sulfur atom in thiophene can also be reduced anaerobically

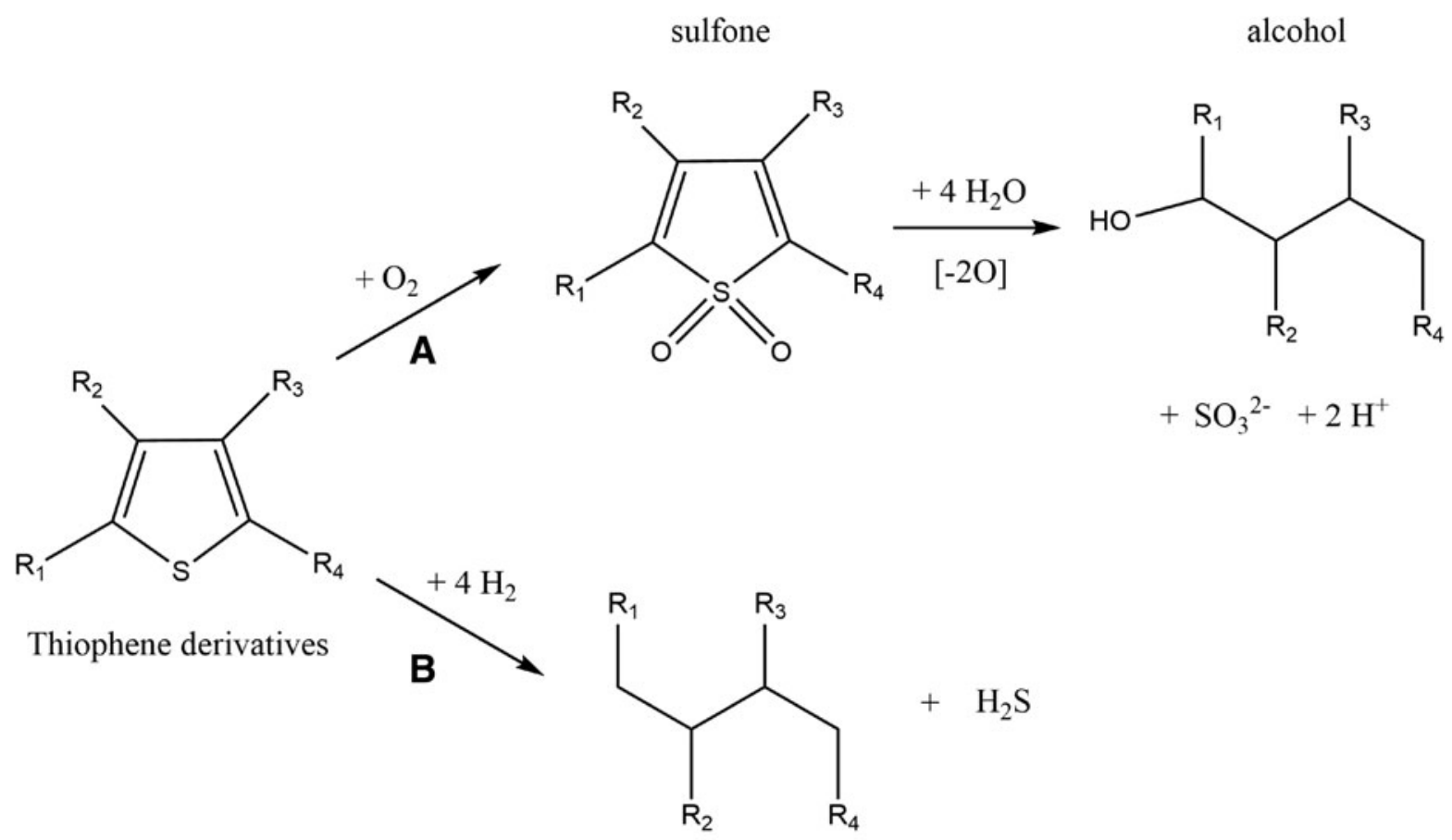

C4 alkane derivatives

FIG. 2. Biodegradation pathways through sulfur-oxidizing (A) or sulfate-reducing (B) microorganisms (Gogoi and Bezbaruah, 2002; Marcelis et al., 2003). 
by sulfate-reducing microbial communities to sulfide (Fig. 2B) (Marcelis et al., 2003). For example, dibenzothiophene can be degraded to biphenyl and $\mathrm{H}_{2} \mathrm{~S}$ by Desulfovibrio desulfuricans (Kim et al., 1990).

\section{Thiophenes on Mars}

\subsection{Detection of martian thiophenes and the correlation with sulfate occurrences}

Thiophene and a few of its derivatives (2-methylthiophene, 3-methylthiophene, and presumably benzothiophene) (Fig. 3) have been detected on Mars together with smaller sulfurcontaining substances (methanethiol, dimethyl sulfide, carbonyl sulfide, carbon disulfide, hydrogen sulfide, and sulfur dioxide) in lacustrine mudstone at Pahrump Hills in the lower Murray formation, Gale Crater, through EGA and pyrolysis-GC-MS onboard the Curiosity rover (Eigenbrode et al., 2018). The total sulfur content of the organic matter is with $\sim 5 \%$ similar to sulfur content in kerogens on Earth (Table 1). In addition, several sulfur-free aliphatic and aromatic compounds have been found. The concentrations of the detected components in the various drill holes reported by Eigenbrode et al. (2018) are summarized in Table 2.

Table 2 reveals that compared with the blank measurements at Cumberland (CB blank, $0.46 \mathrm{nmol}$ ) and Confidence Hills (CH blank, $0.49 \mathrm{nmol}$ ), significant thiophene concentrations appeared only in the samples of $\mathrm{CH}(2.02 \mathrm{nmol})$ and Mojave 2 (MJ, $2.20 \mathrm{nmol})$. However, the slightly increased thiophene concentrations at John Klein (JK, $0.79 \mathrm{nmol})$, Telegraph Peak (TP, $0.70 \mathrm{nmol}$ ), and Buckskin (BK, $0.63 \mathrm{nmol})$ might represent positive thiophene detections close to the detection limit. In contrast, no thiophene seems to be present at $\mathrm{CB}$ because the measured thiophene concentration $(0.26 \mathrm{nmol})$ is below those measured for the blanks.

The mineralogy of the different sites has already been described elsewhere (Grotzinger et al., 2014, 2015; Vaniman et al., 2014; Hurowitz et al., 2017; Rampe et al., 2017).

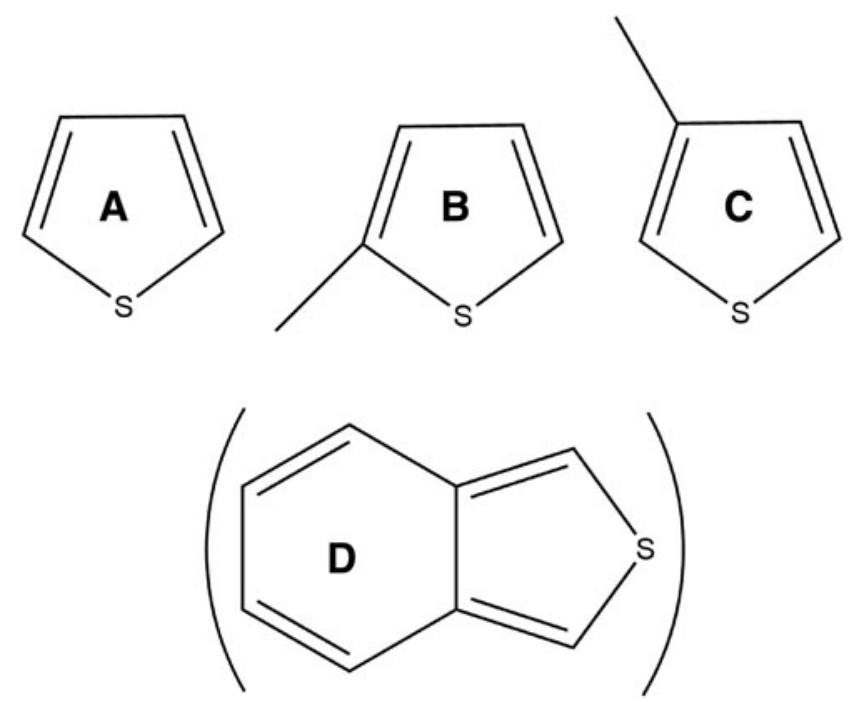

FIG. 3. Thiophene derivatives detected on Mars (Eigenbrode et al., 2018): thiophene (A), 2-methylthiophene (B), 3-methylthiophene (C), presumably benzothiophene (D).
Particularly interesting is a possible correlation between sulfate occurrences and thiophene detections (Fig. 4). MJ, the drill hole with the highest thiophene abundances (Table 2), is also the sample with the highest jarosite $\left[\mathrm{KFe}_{3}(\mathrm{OH})_{6}\left(\mathrm{SO}_{4}\right)_{2}\right]$ concentration $(3.1 \mathrm{wt} \%)$ yet discovered by the Curiosity rover (Martin et al., 2017). In addition, magnesium sulfate $\left(\mathrm{MgSO}_{4}\right)$ has been detected at both thiophene-rich sites (MJ and $\mathrm{CH}$ ) (Nachon et al., 2017), whereas the correlation between the $\mathrm{MgO}$ and $\mathrm{SO}_{3}$ content was significantly lower at $\mathrm{TP}$ and $\mathrm{BK}$, indicating the absence or only low concentrations of $\mathrm{MgSO}_{4}$ (Hurowitz et al., 2017). Furthermore, it has been proposed that $\mathrm{MJ}$ and $\mathrm{CH}$ are situated in a section of the stratigraphic column of the former Gale Crater lake where sulfate precipitation from leached minerals occurred (Rampe et al., 2017), also correlating with the enhanced thiophene abundances in that section.

At $\mathrm{CB}$ and $\mathrm{JK}$, neither jarosite nor $\mathrm{MgSO}_{4}\left[\mathrm{no} \mathrm{MgO} / \mathrm{SO}_{3}\right.$ correlation (Hurowitz et al., 2017)] has been detected, accompanying no or a low thiophene signal, respectively. However, $\mathrm{CaSO}_{4}$ veins appear in the mudstone of the Yellowknife Bay like on various other places along the Curiosity route (Nachon et al., 2017). Nevertheless, the $\mathrm{CaSO}_{4}$ concentration at $\mathrm{CB}$ is very low [0.8 wt \% anhydrite, $0.7 \mathrm{wt} \%$ bassanite (Vaniman et al., 2014)], possibly correlating with the absence of thiophenes. The $\mathrm{CaSO}_{4}$ concentration at $\mathrm{JK}$ is slightly increased [2.6 wt \% anhydrite, $1.9 \mathrm{wt} \%$ bassanite (Vaniman et al., 2014)] and $\mathrm{CaSO}_{4}$ veins are visible in the drill hole (Nachon et al., 2014), correlating with a slightly increased thiophene signal for JK compared with CB (Table 2).

There are several possible explanations for the observed correlation between thiophene and sulfate abundances:

(1) The correlation might be simply the result of sulfur enrichments. An increased content of sulfur nucleophiles would enhance both the formation rate of thiophenes during diagenesis and the sulfate formation through oxidation processes (Eglinton et al., 1992; Sinninghe Damsté and Leeuw, 1992).

(2) Sulfates are known to preserve organic matter $(\mathrm{Au}-$ brey et al., 2006). Hence, the detected sulfate minerals might increase the stability of the thiophenes that formed earlier in the martian history.

(3) Sulfate might be a parent substance of the thiophene formation. A possible biological conversion of sulfates into thiophenes is described in Section 3.2.3.

Independent of the reason for the thiophene/sulfate correlation, we hypothesize that in sediments at Sutton Island (Fig. 4), where the Curiosity rover very recently discovered bulk enrichments of $\mathrm{CaSO}_{4}(30-50 \mathrm{wt} \%)$ and $\mathrm{MgSO}_{4}(26-$ $36 \mathrm{wt} \%$ ) (Rapin et al., 2019), the thiophene concentration might be even higher than at Pahrump Hills. It should be noted that the thiophene/sulfate correlation reported in this study is only semiquantitative, referring on several specific sulfate-bearing minerals, because the total sulfate concentration (including soluble salts such as $\mathrm{MgSO}_{4}$ ) is unknown. Correlations with other geochemical parameters have not been found.

\subsection{Possible origins of thiophene derivatives on Mars}

3.2.1. Meteoric input. Thiophene and several of its derivatives such as benzothiophene and dibenzothiophene have 
Table 2. Concentration of Chemical Compounds Detected Through Evolved Gas Analysis (IN NMOL OF CARBON) (EIgENBROde ET AL., 2018)

\begin{tabular}{|c|c|c|c|c|c|c|c|c|}
\hline & \multicolumn{3}{|c|}{ Yellowknife Bay } & \multicolumn{5}{|c|}{ Murray formation } \\
\hline & $C B$ blank $^{\mathrm{a}}$ & $C B^{\mathrm{a}}$ & $J K$ & $\mathrm{CH}$ blank & $\mathrm{CH}$ & $M J$ & $T P$ & $B K$ \\
\hline \multicolumn{9}{|l|}{ Thiophenes (nmol) } \\
\hline Thiophene & 0.24 & 0.16 & 0.40 & 0.27 & 1.48 & 1.66 & 0.41 & 0.43 \\
\hline Methylthiophene & 0.21 & 0.10 & 0.39 & 0.22 & 0.54 & 0.54 & 0.29 & 0.20 \\
\hline Total thiophene & 0.45 & 0.26 & 0.79 & 0.49 & 2.02 & 2.2 & 0.70 & 0.63 \\
\hline \multicolumn{9}{|c|}{ Nonthiophenic compounds (nmol) } \\
\hline Methanethiol & 0.23 & 0.42 & 1.02 & 0.47 & 13.60 & 23.40 & 8.82 & 8.25 \\
\hline Dimethylsulfide & 0.26 & 0.30 & 0.84 & 0.43 & 5.32 & 6.93 & 4.63 & 2.74 \\
\hline Carbonyl sulfide & 0.19 & 0.49 & 1.11 & 0.50 & 9.18 & 11.90 & 5.69 & 4.68 \\
\hline Carbon disulfide & 0.14 & 0.05 & 0.25 & 0.10 & 1.25 & 1.54 & 0.88 & 0.61 \\
\hline Carbon disulfide & 2.39 & 14.97 & 14.4 & 5.35 & 20.8 & 38.4 & 9.51 & 19 \\
\hline Benzene & 0.78 & 0.27 & 1.18 & 0.94 & 3.12 & 2.12 & 0.74 & 0.90 \\
\hline Toluene & 0.49 & 0.44 & 1.84 & 0.91 & 3.32 & 2.76 & 1.24 & 1.36 \\
\hline Benzoic acid & 0.75 & 0.32 & 1.35 & 1.19 & 1.59 & 2.11 & 0.85 & 0.96 \\
\hline
\end{tabular}

Drill hole abbreviations: JK, John Klein; CB, Cumberland; CH, Confidence Hills; MJ, Mojave 2; TP, Telegraph Peak; BK, Buckskin. Blank values are printed in italic, total thiophene concentrations are printed in bold.

${ }^{a}$ Average values of several measurements. For further information including error values, see Eigenbrode et al. (2018).

been detected in various meteorites, for example, the carbonaceous chondrites in Murchison (Shimoyama and Katsumata, 2001; Sephton, 2004), Murray (Hayes and Biemann, 1968; Sephton, 2002), and Orgueil (Bandurski and Nagy, 1976). Thus, it is plausible to assume that the thiophene derivatives found on Mars are at least partly the result of meteoric impacts. In addition, these cosmic events could provide organic compounds that can react with sulfurization agents to yield thiophene derivatives (Section 3.2.2.).
3.2.2. Abiotic thiophene synthesis on Mars. Similar to the formation of thiophenic compounds on Earth (Section 2.1.), it is conceivable that the sulfur-rich organic matter on Mars formed during early diagenesis by reaction of sulfur nucleophiles with organic matter. The sulfur nucleotides might have been transported in the form of sulfides through hydrothermal groundwater to the Gale crater lake (Franz et al., 2017) or might be biological in origin (see Section 3.2.3). The organic substances might be of cosmic origin (infall of extraterrestrial

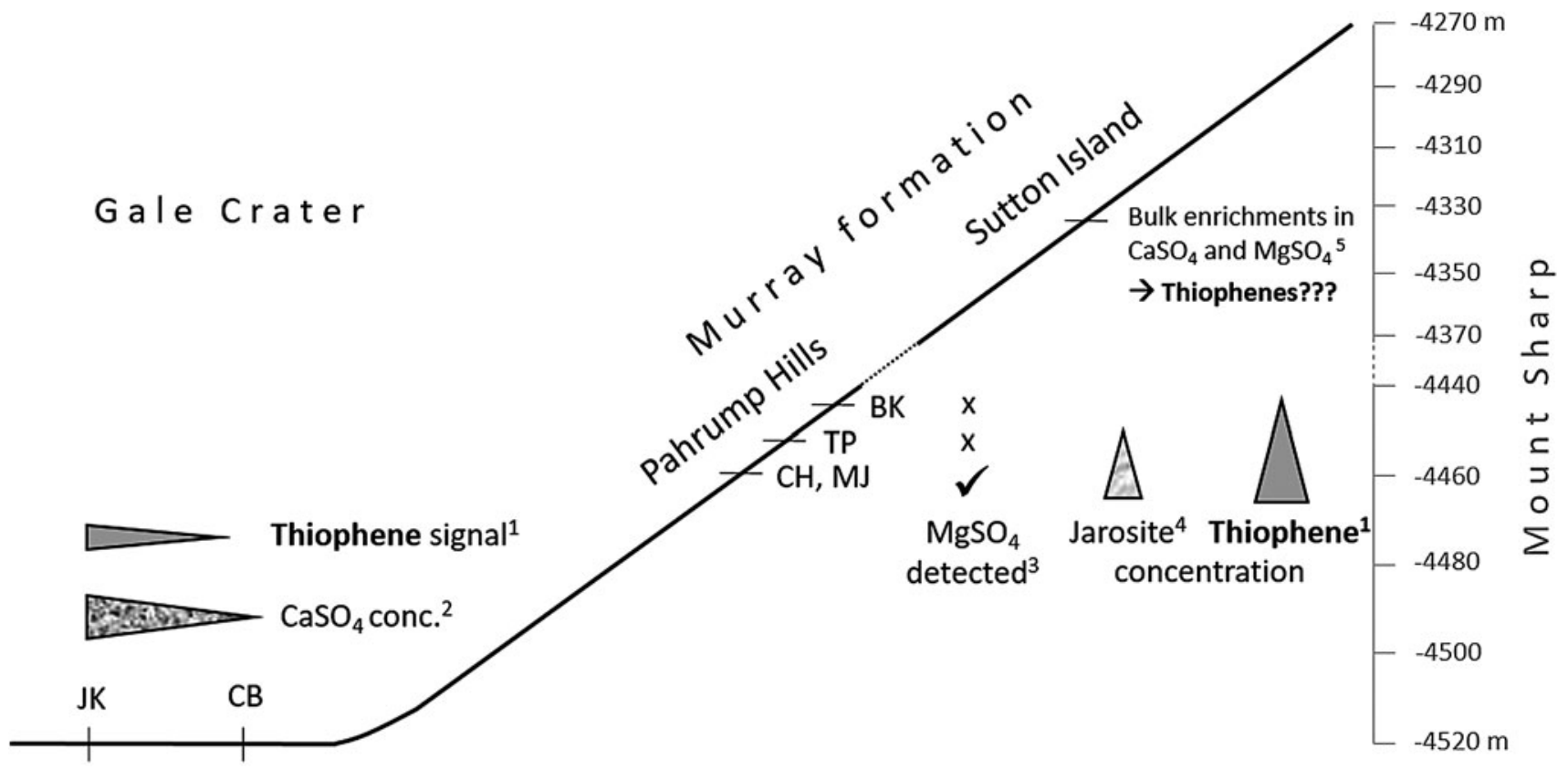

Yellowknife Bay

FIG. 4. Stratigraphic context in the Gale Crater on the correlation between thiophene and sulfate abundances in mudstones (Yellowknife Bay and Pahrump Hills) and bedrock (Sutton Island). References: ${ }^{1}$ Eigenbrode et al. (2018), ${ }^{2}$ Vaniman et al. (2014), ${ }^{3}$ Hurowitz et al. (2017), ${ }^{4}$ Rampe et al. (2017), ${ }^{5}$ Rapin et al. (2019). 
carbonaceous material), a product of abiotic organic synthesis on igneous rocks (Steele et al., 2016), or even of biological origin. Indeed, in the martian Sheepbed mudstone, organic molecules with a four-carbon chain $\left(\mathrm{C}_{4}\right)$ have been detected (Freissinet et al. 2015). $\mathrm{C}_{4}$ compounds can react with sulfurizing agents such as elemental sulfur, hydrogen sulfide, sulfur oxides, or metal sulfides in a ring-closing condensation reaction to thiophene or its derivatives (Campaigne, 1984).

It is very likely that during diagenesis, the formed thiophenes are directly incorporated into kerogen-like macromolecular structures, which would be more stable than the single molecules. A hypothetical macromolecular structure representing the organic molecules detected at $\mathrm{MJ}$ and $\mathrm{CH}$ is presented in Fig. 5. These large structures would break up during pyrolysis and would provide the fragments detected through EGA and GC-MS (Eigenbrode et al., 2018).

3.2.3. Biosynthesis and thiophenes as biomarkers on Mars. Nucleophilic sulfur species are needed for the diagenetic thiophene synthesis described previously. However, the majority of available sulfur on Mars exists in the form of non-nucleophilic sulfates (King and McLennan, 2010). Sulfate can be reduced into nucleophilic sulfide species by thermochemical sulfate reduction at temperatures $>120^{\circ} \mathrm{C}$ (Goldstein and Aizenshtat, 1994). A possibility to transform sulfates into sulfides also at low temperatures is given by bacterial sulfate reduction (BSR).
For example, the mineral jarosite detected on Mars by the Curiosity rover (e.g., at $\mathrm{CH}$ and MJ, Fig. 4) as well as the Opportunity rover (Christensen et al., 2004) could have been converted to $\mathrm{H}_{2} \mathrm{~S}$ through reductive dissolution by sulfatereducing bacteria (Gao et al., 2019). The formation of jarosite requires acid environmental conditions ( $\mathrm{pH} \mathrm{2-6)}$ and possibly occurred on Mars by postdepositional sediment reactions with an acidic oxidizing fluid flowing through the Pahrump Hills area (Rampe et al., 2017). Additional moderately acid conditions on Mars have been proposed accompanying the lack of large carbonate deposits (Fairén et al., 2004).

BSR under these acid conditions is possible, although it is more common in natural environments with $\mathrm{pH}>6$ (Koschorreck, 2008). An example for the occurrence of BSR in a natural acidic environment is the Río Tinto in the Iberian Pyritic Belt (Amils et al., 2007; Sánchez-Andrea et al. 2011). Nevertheless, the environmental conditions at the thiophene-bearing sites could not have been extremely acid for a long period, because otherwise the detected organic compounds (and some $\mathrm{pH}$ sensitive minerals such as olivine or apatite) would have been oxidized or destroyed (Eigenbrode et al., 2018).

Furthermore, BSR is feasible at subzero temperature prevailing on Mars (Knoblauch and Jorgensen, 1999). Therefore, BSR has been suggested as a plausible metabolism pathway on ancient Mars and in the subsurface of Mars today (Marnocha et al., 2010). The sulfide formed through BSR of martian sulfates could have been triggering the

\section{Methylthiophenes}

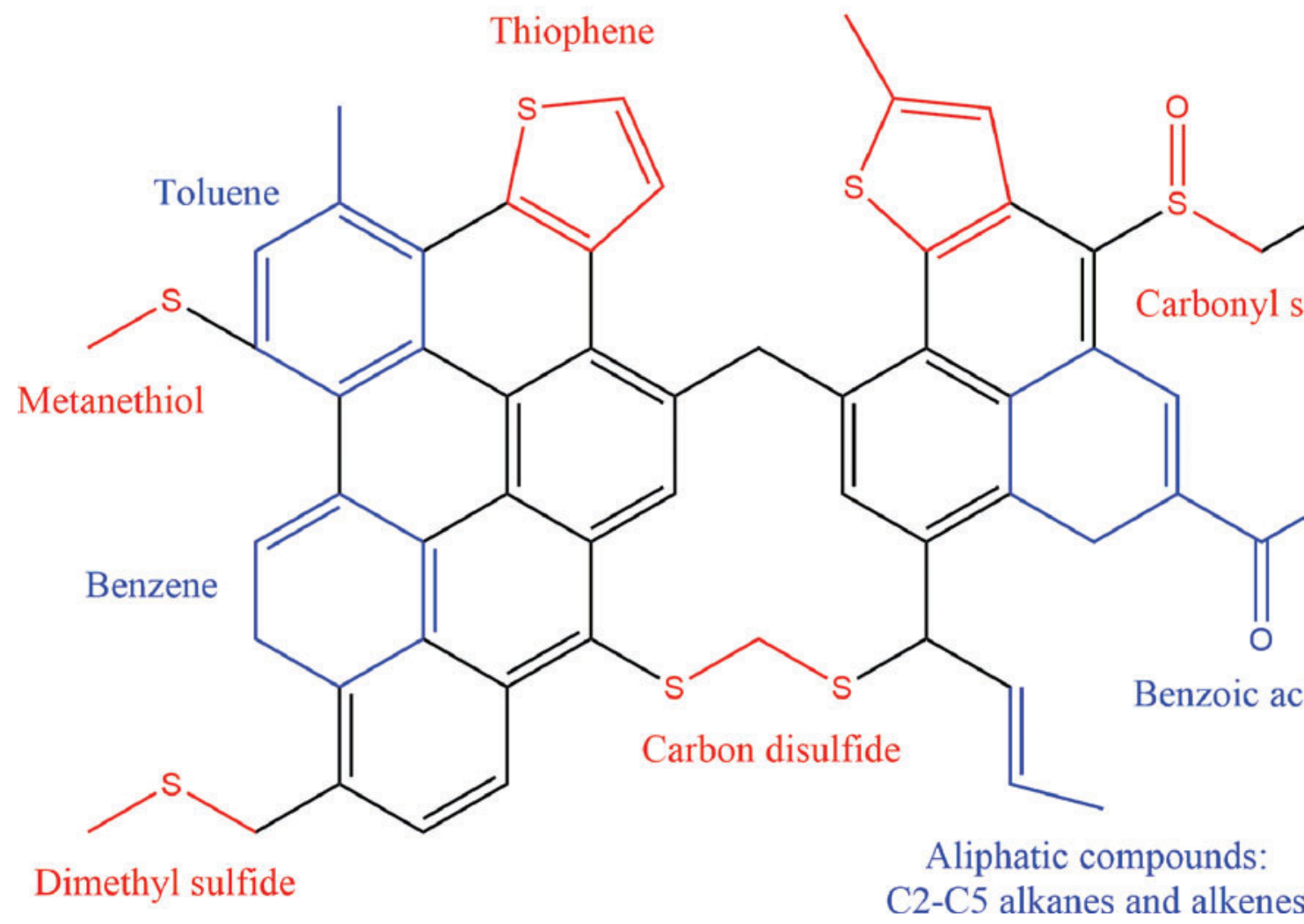

FIG. 5. Hypothetical macromolecular structure of the organic material detected at Pahrump Hills. Sulfur-containing and sulfur-free structures detected through evolved gas analysis are shown in red and in blue, respectively. Color images are available online. 
diagenetic thiophene production on ancient Mars and could help to explain the observed correlation between sulfate and thiophene abundances (Fig. 4).

Especially the detection of isoprenoid thiophenes would be of huge astrobiological interest because it would hint either toward the biotic synthesis of the precursors such as phytenes (Section 2.1.) or toward their direct biosynthesis similar to the formation of CQ or BDTQ (Section 2.2.). In both cases, they could be considered as martian biomarkers. If these isoprenoid thiophenes were present in the Pahrump Hill samples, the heating during pyrolysis $\left(500-820^{\circ} \mathrm{C}\right.$ for EGA) would have destroyed these more fragile compounds and revealed smaller fragments with a higher thermal stability, like the detected methyl thiophenes and alkanes and alkenes of various chain lengths.

3.2.4. Biodegradation of thiophenes on Mars. Theoretically, the thiophenic compounds-independent of their formation pathway-could also be biodegraded by putative heterotrophic martian microorganisms as described in Section 2.3. In this case, the anaerobic degradation of thiophenes by sulfate-reducing bacteria seems to be a more realistic scenario for the predominantly anaerobic conditions on Mars, especially since this type of bacteria could drive the thiophene production in the first place (Section 3.2.3.). It could even be speculated that the $\mathrm{C}_{4}$ dichloroalkanes detected on Mars (Freissinet et al. 2015) might be the result of anaerobic degradation of chlorinated thiophenes following the equation from Fig. $2 \mathrm{~B}$ with two of the residues (R1-R4) substituted by chlorine.

\section{Discussion and Recommendations}

We briefly summarized conceivable production and degradation pathways of thiophenes detected on Mars by the Curiosity rover and evaluated their potential in serving as biomarkers. With the available data, none of the presented thiophene formation pathways can be ruled out. Certainly, the biosynthesis of thiophenes is the most fascinating option; however, more detailed analyses are needed to support or discard this possibility.

In future Mars missions, more structurally sensitive (less destructive) instrumentation is needed since the pyrolysisbased techniques used by the Curiosity rover provide only information on fragments of organic matter. The Mars Organic Molecule Analyzer onboard the Rosalind Franklin rover (expected to be launched in July 2020) will provide the necessary nondestructive analyzing method by using laser desorption mass spectrometry to characterize organic molecules and putative biomarkers (Goesmann et al., 2017).

Isotopic analyses of the martian organic matter would be helpful to distinguish an abiotic origin from a biotic origin. Biotically produced organic compounds are expected to be enriched in lighter isotopes, for example, lower ${ }^{13} \mathrm{C} /{ }^{12} \mathrm{C}$ ratios, compared with organic compounds formed abiotically (Schidlowski, 1992; Schulze-Makuch and Irwin, 2018). Although a decreased ${ }^{13} \mathrm{C} /{ }^{12} \mathrm{C}$ ratio alone cannot provide a definite proof for the presence of martian life, carbon isotopic data would nevertheless be very useful in determining prebiotic carbon transformations on Mars (Rothschild and DesMarais, 1989).

Sulfur isotopic ratios may be even more revealing, especially when comparing thiophenes produced by biota with abiotically deposited sulfur sources such as sulfate minerals (van Zuilen, 2008). In contrast to carbon isotopic analyses that are lacking for martian samples to date, in situ analyses of the sulfur isotopic compositions of $\mathrm{SO}_{2}$ volatilized from sediment samples have been carried out recently by the Curiosity rover (Franz et al., 2017). The experiments revealed large sulfur isotope fractionations $\left(\delta^{34} S\right)$ ranging from $-47 \pm 14 \%$ to $+28 \pm 7 \%$. Interestingly, this range closely reflects observed isotopic fractionations between sulfide and sulfate $(-42$ to $+28 \%$ of the Haughton impact structure in the Canadian High Arctic, which is interpreted to result from biological sulfate reduction in an impactgenerated hydrothermal system (Parnell et al., 2010; Franz et al., 2017). Certainly, this is no proof that martian sulfur compounds (including thiophenes) are of biological origin but should prompt further investigations.

One of these investigations could be laboratory experiments to explore the possible biotic production of thiophenes under simulated martian conditions. Microbial growth and production of thiophenes may be possible under martian environmental niche conditions (near subsurface), if sufficient adaptation time is provided (de Vera et al., 2014). Furthermore, it can be assumed that microbial thiophene production occurred only on early Mars with its more habitable conditions. Thus, laboratory experiments should also be conducted for this early Mars scenario that might include increased pressures, warmer but still subzero temperatures, as well as saline and slightly acidic liquid water (Fairén et al., 2009). If microbial thiophene production could successfully be simulated under these conditions in the laboratory, also the isotopic fractionation in source materials, metabolic intermediates, and metabolic end products should be determined to evaluate experimental data obtained from Mars.

\section{Acknowledgments}

We thank the reviewers Alberto Fairén and Chris McKay for constructive reviews, which were detailed and included many helpful suggestions.

\section{Author Disclosure Statement}

No competing financial interests exist.

\section{Funding Information}

This project was funded by European Research Council Advanced Grant "Habitability of Martian Environments" (HOME, No. 339231).

\section{References}

Amils, R., González-Toril, E., Fernández-Remolar, D., Gómez, F., Aguilera, Á., Rodríguez, N., Malki, M., GarcíaMoyano, A., Fairén, A.G., La Fuente, V. de, and Luis Sanz, J. (2007) Extreme environments as Mars terrestrial analogs: The Rio Tinto case. Planet Space Sci 55:370-381.

Aubrey, A., Cleaves, H.J., Chalmers, J.H., Skelley, A.M., Mathies, R.A., Grunthaner, F.J., Ehrenfreund, P., and Bada, J.L. (2006) Sulfate minerals and organic compounds on Mars. Geology 34: 357.

Bandurski, E.L. and Nagy, B. (1976) The polymer-like organic material in the Orgueil meteorite. Geochim Cosmochim Acta 40:1397-1406. 
Berner, R.A., Leeuw, J.W.D., Spiro, B., Murchison, D.G., and Eglinton, G. (1985) Sulphate reduction, organic matter decomposition and pyrite formation [and discussion]. Phil Trans Roy Soc A Math Phys Eng Sci 315:25-38.

Brassell, S.C., Lewis, C.A., Leeuw, J.W. de, Lange, F. de, and Damsté, J.S.S. (1986) Isoprenoid thiophenes: Novel products of sediment diagenesis? Nature 320:160-162.

Campaigne, E. (1984) Thiophenes and their benzo derivatives: (III) synthesis and applications. In Comprehensive Heterocyclic Chemistry, Pergamon Press, Oxford, UK, pp 863-934.

Christensen, P.R., Wyatt, M.B., Glotch, T.D., Rogers, A.D., Anwar, S., Arvidson, R.E., Bandfield, J.L., Blaney, D.L., Budney, C., Calvin, W.M., Fallacaro, A., Fergason, R.L., Gorelick, N., Graff, T.G., Hamilton, V.E., Hayes, A.G., Johnson, J.R., Knudson, A.T., McSween, H.Y., Mehall, G.L., Mehall, L.K., Moersch, J.E., Morris, R.V., Smith, M.D., Squyres, S.W., Ruff, S.W., and Wolff, M.J. (2004) Mineralogy at Meridiani Planum from the mini-TES experiment on the Opportunity rover. Science 306:1733-1739.

Craddock, P.R., Bake, K.D., and Pomerantz, A.E. (2018) Chemical, molecular, and microstructural evolution of kerogen during thermal maturation: case study from the Woodford Shale of Oklahoma. Energy Fuels 32:4859-4872.

De Leeuw, J.W. and Sinninghe Damsté, J.S. (1990) Organic Sulfur Compounds and Other Biomarkers as Indicators of Palaeosalinity. In Geochemistry of Sulfur in Fossil Fuels, ACS Symposium Series, edited by W.L. Orr and C.M. White, American Chemical Society, Washington, DC, pp 417-443.

de Rosa, M., Gambacorts, A., and Minale, L. (1975) A terpenoid 4,7-thianaphthenequinone from an extremely thermophilic and acidophilic micro-organism. $J$ Chem Soc Chem Commun 392. doi: 10.1039/C39750000392

de Rosa, M., Rosa, S. de, Gambacorta, A., Minale, L., Thomson, R.H., and Worthington, R.D. (1977) Caldariellaquinone, a unique benzo[b]thiophen-4,7-quinone from Caldariella acidophila, an extremely thermophilic and acidophilic bacterium. J Chem Soc Perkin Trans 1 653. doi: 10.1039/P19770000653

de Vera, J.-P., Schulze-Makuch, D., Khan, A., Lorek, A., Koncz, A., Möhlmann, D., and Spohn, T. (2014) Adaptation of an Antarctic lichen to Martian niche conditions can occur within 34 days. Planet Space Sci 98:182-190.

Eglinton, T.I., Sinninghe Damsté, J.S., Pool, W., De Leeuw, J.W., Eijk, G., and Boon, J.J. (1992) Organic sulphur in macromolecular sedimentary organic matter. II. Analysis of distributions of sulphur-containing pyrolysis products using multivariate techniques. Geochim Cosmochim Acta 56:1545-1560.

Eigenbrode, J.L., Summons, R.E., Steele, A., Freissinet, C., Millan, M., Navarro-González, R., Sutter, B., McAdam, A.C., Franz, H.B., Glavin, D.P., Archer, P.D., Mahaffy, P.R., Conrad, P.G., Hurowitz, J.A., Grotzinger, J.P., Gupta, S., Ming, D.W., Sumner, D.Y., Szopa, C., Malespin, C., Buch, A., and Coll, P. (2018) Organic matter preserved in 3-billion-year-old mudstones at Gale crater, Mars. Science 360:1096-1101.

Fairén, A.G., Fernández-Remolar, D., Dohm, J.M., Baker, V.R., and Amils, R. (2004) Inhibition of carbonate synthesis in acidic oceans on early Mars. Nature 431:423-426.

Fairén, A.G., Davila, A.F., Gago-Duport, L., Amils, R., and McKay, C.P. (2009) Stability against freezing of aqueous solutions on early Mars. Nature 459:401-404.

Franz, H.B., McAdam, A.C., Ming, D.W., Freissinet, C., Mahaffy, P.R., Eldridge, D.L., Fischer, W.W., Grotzinger, J.P., House, C.H., Hurowitz, J.A., McLennan, S.M., Schwenzer, S.P., Vaniman, D.T., Archer Jr, P.D., Atreya,
S.K., Conrad, P.G., Dottin III, J.W., Eigenbrode, J.L., Farley, K.A., Glavin, D.P., Johnson, S.S., Knudson, C.A., Morris, R.V., Navarro-González, R., Pavlov, A.A., Plummer, R., Rampe, E.B., Stern, J.C., Steele, A., Summons, R.E., and Sutter, B. (2017) Large sulfur isotope fractionations in Martian sediments at Gale crater. Nature Geosci 10:658-662. Freissinet, C., Glavin, D.P., Mahaffy, P.R., Miller, K.E., Eigenbrode, J.L., Summons, R.E., Brunner, A.E., Buch, A., Szopa, C., Archer, P.D., Franz, H.B., Atreya, S.K., Brinckerhoff, W.B., Cabane, M., Coll, P., Conrad, P.G., Des Marais, D.J., Dworkin, J.P., Fairén, A.G., François, P., Grotzinger, J.P., Kashyap, S., Kate, I.L. ten, Leshin, L.A., Malespin, C.A., Martin, M.G., Martin-Torres, F.J., McAdam, A.C., Ming, D.W., Navarro-González, R., Pavlov, A.A., Prats, B.D., Squyres, S.W., Steele, A., Stern, J.C., Sumner, D.Y., Sutter, B., and Zorzano, M.-P. (2015) Organic molecules in the Sheepbed Mudstone, Gale Crater, Mars. J Geophys Res Planets 120:495-514.

Gao, K., Jiang, M., Guo, C., Zeng, Y., Fan, C., Zhang, J., Reinfelder, J.R., Huang, W., Lu, G., and Dang, Z. (2019) Reductive dissolution of jarosite by a sulfate reducing bacterial community: Secondary mineralization and microflora development. Sci Total Environ 690:1100-1109.

Goesmann, F., Brinckerhoff, W.B., Raulin, F., Goetz, W., Danell, R.M., Getty, S.A., Siljeström, S., Mißbach, H., Steininger, H., Arevalo, R.D., Buch, A., Freissinet, C., Grubisic, A., Meierhenrich, U.J., Pinnick, V.T., Stalport, F., Szopa, C., Vago, J.L., Lindner, R., Schulte, M.D., Brucato, J.R., Glavin, D.P., Grand, N., Li, X., and van Amerom, Friso H.W. (2017) The Mars Organic Molecule Analyzer (MOMA) Instrument: characterization of organic material in martian sediments. Astrobiology 17:655-685.

Gogoi, B.K. and Bezbaruah, R.L. (2002) Microbial degradation of sulfur compounds present in coal and petroleum. In Progress in Industrial Microbiology Biotransformations, edited by S. Ved Pal and S. Raymond D., Elsevier, Amsterdam, pp 427-456.

Goldstein, T.P. and Aizenshtat, Z. (1994) Thermochemical sulfate reduction a review. J Thermal Anal 42:241-290.

Grotzinger, J.P., Sumner, D.Y., Kah, L.C., Stack, K., Gupta, S., Edgar, L., Rubin, D., Lewis, K., Schieber, J., Mangold, N., Milliken, R., Conrad, P.G., DesMarais, D., Farmer, J., Siebach, K., Calef, F., Hurowitz, J., McLennan, S.M., Ming, D., Vaniman, D., Crisp, J., Vasavada, A., Edgett, K.S., Malin, M., Blake, D., Gellert, R., Mahaffy, P., Wiens, R.C., Maurice, S., Grant, J.A., Wilson, S., Anderson, R.C., Beegle, L., Arvidson, R., Hallet, B., Sletten, R.S., Rice, M., Bell, J., Griffes, J., Ehlmann, B., Anderson, R.B., Bristow, T.F., Dietrich, W.E., Dromart, G., Eigenbrode, J., Fraeman, A., Hardgrove, C., Herkenhoff, K., Jandura, L., Kocurek, G., Lee, S., Leshin, L.A., Leveille, R., Limonadi, D., Maki, J., McCloskey, S., Meyer, M., Minitti, M., Newsom, H., Oehler, D., Okon, A., Palucis, M., Parker, T., Rowland, S., Schmidt, M., Squyres, S., Steele, A., Stolper, E., Summons, R., Treiman, A., Williams, R., and Yingst, A. (2014) A habitable fluvio-lacustrine environment at Yellowknife Bay, Gale crater, Mars. Science (New York) 343:1242777.

Grotzinger, J.P., Gupta, S., Malin, M.C., Rubin, D.M., Schieber, J., Siebach, K., Sumner, D.Y., Stack, K.M., Vasavada, A.R., Arvidson, R.E., Calef, F., Edgar, L., Fischer, W.F., Grant, J.A., Griffes, J., Kah, L.C., Lamb, M.P., Lewis, K.W., Mangold, N., Minitti, M.E., Palucis, M., Rice, M., Williams, R.M.E., Yingst, R.A., Blake, D., Blaney, D., Conrad, P., Crisp, J., Dietrich, W.E., Dromart, G., Edgett, K.S., Ewing, 
R.C., Gellert, R., Hurowitz, J.A., Kocurek, G., Mahaffy, P., McBride, M.J., McLennan, S.M., Mischna, M., Ming, D., Milliken, R., Newsom, H., Oehler, D., Parker, T.J., Vaniman, D., Wiens, R.C., and Wilson, S.A. (2015) Deposition, exhumation, and paleoclimate of an ancient lake deposit, Gale crater, Mars. Science (New York) 350:aac7575.

Guzman, M., McKay, C.P., Quinn, R.C., Szopa, C., Davila, A.F., Navarro-González, R., and Freissinet, C. (2018) Identification of chlorobenzene in the Viking gas chromatographmass spectrometer data sets: reanalysis of Viking Mission data consistent with aromatic organic compounds on Mars. J Geophys Res Planets 123:1674-1683.

Hayes, J.M. and Biemann, K. (1968) High resolution mass spectrometric investigations of the organic constituents of the Murray and Holbrook chondrites. Geochim Cosmochim Acta 32:239-267.

Hurowitz, J.A., Grotzinger, J.P., Fischer, W.W., McLennan, S.M., Milliken, R.E., Stein, N., Vasavada, A.R., Blake, D.F., Dehouck, E., Eigenbrode, J.L., Fairén, A.G., Frydenvang, J., Gellert, R., Grant, J.A., Gupta, S., Herkenhoff, K.E., Ming, D.W., Rampe, E.B., Schmidt, M.E., Siebach, K.L., StackMorgan, K., Sumner, D.Y., and Wiens, R.C. (2017) Redox stratification of an ancient lake in Gale crater, Mars. Science (New York) 356. doi: 10.1126/science.aah6849

Juhl, M.J. and Clark, D.P. (1990) Thiophene-degrading Escherichia coli mutants possess sulfone oxidase activity and show altered resistance to sulfur-containing antibiotics. Appl Environ Microbiol 56:3179-3185.

Kenig, F. and Huc, A.Y. (1990) Incorporation of Sulfur into Recent Organic Matter in a Carbonate Environment (Abu Dhabi, United Arab Emirates). In Geochemistry of Sulfur in Fossil Fuels, ACS Symposium Series, edited by W.L. Orr and C.M. White, American Chemical Society, Washington, DC, pp 170-185.

Kertesz, M.A. (2000) Riding the sulfur cycle-metabolism of sulfonates and sulfate esters in Gram-negative bacteria. FEMS Microbiol Rev 24:135-175.

Kim, Yeong, H., Kim, T.S., and Kim, B.H. (1990) Degradation of organic sulfur compounds and the reduction of dibenzothiophene to biphenyl and hydrogen sulfide by $D e$ sulfovibrio desulfuricans M6. Biotechnol Lett 12:761-764.

King, P.L. and McLennan, S.M. (2010) Sulfur on Mars. Elements 6:107-112.

Knoblauch, C. and Jorgensen, B.B. (1999) Effect of temperature on sulphate reduction, growth rate and growth yield in five psychrophilic sulphate-reducing bacteria from Arctic sediments. Environ Microbiol 1:457-467.

Kohnen, M.E.L., Sinninghe Damste, J.S., and De Leeuw, J.W. (1991) Biases from natural sulphurization in palaeoenvironmental reconstruction based on hydrocarbon biomarker distributions. Nature 349:775-778.

Koopmans, M.P., Sinninghe Damsté, J.S., Lewan, M.D., and De Leeuw, J.W. (1995) Thermal stability of thiophene biomarkers as studied by hydrous pyrolysis. Org Geochem 23:583-596.

Koopmans, M.P., De Leeuw, J.W., Lewan, M.D., and Sinninghe Damste, J.S. (1996) Impact of dia- and catagenesis on sulphur and oxygen sequestration of biomarkers as revealed by artificial maturation of an immature sedimentary rock. Org Geochem 25:391-426.

Koschorreck, M. (2008) Microbial sulphate reduction at a low pH. FEMS Microbiol Ecol 64:329-342.

Krein, E.B. (1993) Organic sulfur in the geosphere: analysis, structures and chemical processes. In Sulphur-Containing Functional Groups (1993), edited by S. Patai and Z. Rappoport, John Wiley \& Sons, Inc, Chichester, UK, pp 975-1032.
Krein, E.B. and Aizenshtat, Z. (1994) The formation of isoprenoid sulfur compounds during diagenesis: simulated sulfur incorporation and thermal transformation. Org Geochem 21: $1015-1025$.

Lanzotti, V., Trincone, A., Gambacorta, A., Rosa, M. de, and Breitmaier, E. (1986) $1 \mathrm{H}$ and 13C NMR assignment of benzothiophenquinones from the sulfur-oxidizing archaebacterium Sulfolobus solfataricus. Eur J Biochem 160:37-40.

Lemelle, L., Labrot, P., Salomé, M., Simionovici, A., Viso, M., and Westall, F. (2008) In situ imaging of organic sulfur in 700800 My-old Neoproterozoic microfossils using X-ray spectromicroscopy at the S K-edge. Org Geochem 39:188-202.

Lepot, K., Benzerara, K., Rividi, N., Cotte, M., Brown, G.E., and Philippot, P. (2009) Organic matter heterogeneities in 2.72Ga stromatolites: Alteration versus preservation by sulfur incorporation. Geochim Cosmochim Acta 73:6579-6599.

Marcelis, C., Ivanova, A.E., Janssen, A., and Stams, A. (2003) Anaerobic desulphurisation of thiophenes by mixed microbialcommunities from oilfields. Biodegradation 14:173-182.

Marnocha, C.L., Chevrier, V.F., and Ivey, M. (2010) Sulfatereducing bacteria as a model for life in the Martian subsurface [abstract 1536]. In 41st Lunar and Planetary Science Conference abstracts. The Woodlands, Texas.

Martin, P.E., Farley, K.A., Baker, M.B., Malespin, C.A., Schwenzer, S.P., Cohen, B.A., Mahaffy, P.R., McAdam, A.C., Ming, D.W., Vasconcelos, P.M., and NavarroGonzález, R. (2017) A two-step K-Ar experiment on Mars: dating the diagenetic formation of jarosite from Amazonian groundwaters. J Geophys Res Planets 122:2803-2818.

Montgomery, W., Jaramillo, E.A., Royle, S.H., Kounaves, S.P., Schulze-Makuch, D., and Sephton, M.A. (2019) Effects of oxygen-containing salts on the detection of organic biomarkers on Mars and in terrestrial analog soils. Astrobiology 19:711-721.

Nachon, M., Clegg, S.M., Mangold, N., Schröder, S., Kah, L.C., Dromart, G., Ollila, A., Johnson, J.R., Oehler, D.Z., Bridges, J.C., Le Mouélic, S., Forni, O., Wiens, R.C., Anderson, R.B., Blaney, D.L., Bell, J.F., Clark, B., Cousin, A., Dyar, M.D., Ehlmann, B., Fabre, C., Gasnault, O., Grotzinger, J., Lasue, J., Lewin, E., Léveillé, R., McLennan, S., Maurice, S., Meslin, P.-Y., Rapin, W., Rice, M., Squyres, S.W., Stack, K., Sumner, D.Y., Vaniman, D., and Wellington, D. (2014) Calcium sulfate veins characterized by ChemCam/Curiosity at Gale crater, Mars. J Geophys Res Planets 119:1991-2016.

Nachon, M., Mangold, N., Forni, O., Kah, L.C., Cousin, A., Wiens, R.C., Anderson, R., Blaney, D., Blank, J.G., Calef, F., Clegg, S.M., Fabre, C., Fisk, M.R., Gasnault, O., Grotzinger, J.P., Kronyak, R., Lanza, N.L., Lasue, J., Le Deit, L., Le Mouélic, S., Maurice, S., Meslin, P.-Y., Oehler, D.Z., Payré, V., Rapin, W., Schröder, S., Stack, K., and Sumner, D. (2017) Chemistry of diagenetic features analyzed by ChemCam at Pahrump Hills, Gale crater, Mars. Icarus 281:121-136.

Navarro-González, R., Vargas, E., La Rosa, J. de, Raga, A.C., and McKay, C.P. (2010) Reanalysis of the Viking results suggests perchlorate and organics at midlatitudes on Mars. $J$ Geophys Res 115:281.

Orr, W.L. and Sinninghe Damsté, J.S. (1990) Geochemistry of Sulfur in Petroleum Systems. In Geochemistry of Sulfur in Fossil Fuels, ACS Symposium Series, edited by W.L. Orr and C.M. White, American Chemical Society, Washington, DC, pp 2-29.

Parnell, J., Boyce, A., Thackrey, S., Muirhead, D., Lindgren, P., Mason, C., Taylor, C., Still, J., Bowden, S., Osinski, G.R., and Lee, P. (2010) Sulfur isotope signatures for rapid colonization of an impact crater by thermophilic microbes. Geology 38:271-274. 
Pomerantz, A.E., Bake, K.D., Craddock, P.R., Kurzenhauser, K.W., Kodalen, B.G., Mitra-Kirtley, S., and Bolin, T.B. (2014) Sulfur speciation in kerogen and bitumen from gas and oil shales. Org Geochem 68:5-12.

Rampe, E.B., Ming, D.W., Blake, D.F., Bristow, T.F., Chipera, S.J., Grotzinger, J.P., Morris, R.V., Morrison, S.M., Vaniman, D.T., Yen, A.S., Achilles, C.N., Craig, P.I., Des Marais, D.J., Downs, R.T., Farmer, J.D., Fendrich, K.V., Gellert, R., Hazen, R.M., Kah, L.C., Morookian, J.M., Peretyazhko, T.S., Sarrazin, P., Treiman, A.H., Berger, J.A., Eigenbrode, J., Fairén, A.G., Forni, O., Gupta, S., Hurowitz, J.A., Lanza, N.L., Schmidt, M.E., Siebach, K., Sutter, B., and Thompson, L.M. (2017) Mineralogy of an ancient lacustrine mudstone succession from the Murray formation, Gale crater, Mars. Earth Planet Sci Lett 471:172-185.

Rapin, W., Ehlmann, B.L., Dromart, G., Schieber, J., Thomas, N.H., Fischer, W.W., Fox, V.K., Stein, N.T., Nachon, M., Clark, B.C., Kah, L.C., Thompson, L., Meyer, H.A., Gabriel, T.S.J., Hardgrove, C., Mangold, N., Rivera-Hernandez, F., Wiens, R.C., and Vasavada, A.R. (2019) An interval of high salinity in ancient Gale crater lake on Mars. Nat Geosci 241:21.

Rothschild, L.J. and DesMarais, D. (1989) Stable carbon isotope fractionation in the search for life on early mars. Adv Space Res 9:159-165.

Sánchez-Andrea, I., Rodríguez, N., Amils, R., and Sanz, J.L. (2011) Microbial diversity in anaerobic sediments at Rio Tinto, a naturally acidic environment with a high heavy metal content. Appl Environ Microbiol 77:6085-6093.

Schidlowski, M. (1992) Stable carbon isotopes: Possible clues to early life on Mars. Adv Space Res 12:101-110.

Schulze-Makuch, D. and Irwin, L.N. (2018) Life in the Universe: Expectations and Constraints, $3^{\text {rd }}$ ed. Astronomy and Planetary Science, Springer, Cham, Switzerland.

Sephton, M.A. (2002) Organic compounds in carbonaceous meteorites. Nat Prod Rep 19:292-311.

Sephton, M.A. (2004) Organic matter in ancient meteorites. Astron Geophys 45:2.08-2.14.

Shimoyama, A. and Katsumata, H. (2001) Polynuclear aromatic thiophenes in the Murchison carbonaceous chondrite. Chem Lett 30:202-203.

Simoneit, B.R.T. (2005) A review of current applications of mass spectrometry for biomarker/molecular tracer elucidation. Mass Spectrom Rev 24:719-765.

Sinninghe Damsté, J.S. and De Leeuw, J.W. (1992) Organically bound sulphur in coal: A molecular approach. Fuel Process Technol 30:109-178.

Sinninghe Damsté, J.S., Rijpstra, W.C., Kock-van Dalen, A., De Leeuw, J.W., and Schenck, P. (1989) Quenching of labile functionalised lipids by inorganic sulphur species: Evidence for the formation of sedimentary organic sulphur compounds at the early stages of diagenesis. Geochim Cosmochim Acta 53:1343-1355.

Sinninghe Damsté, J.S., White, C.M., Green, J.B., and De Leeuw, J.W. (1999) Organosulfur compounds in sulfur-rich Raša coal. Energy Fuels 13:728-738.

Splivallo, R., Deveau, A., Valdez, N., Kirchhoff, N., Frey-Klett, P., and Karlovsky, P. (2015) Bacteria associated with trufflefruiting bodies contribute to truffle aroma. Environ Microbiol 17:2647-2660.
Steele, A., McCubbin, F.M., and Fries, M.D. (2016) The provenance, formation, and implications of reduced carbon phases in Martian meteorites. Meteorit Planet Sci 51:2203-2225.

Vaniman, D.T., Bish, D.L., Ming, D.W., Bristow, T.F., Morris, R.V., Blake, D.F., Chipera, S.J., Morrison, S.M., Treiman, A.H., Rampe, E.B., Rice, M., Achilles, C.N., Grotzinger, J.P., McLennan, S.M., Williams, J., Bell, J.F., Newsom, H.E., Downs, R.T., Maurice, S., Sarrazin, P., Yen, A.S., Morookian, J.M., Farmer, J.D., Stack, K., Milliken, R.E., Ehlmann, B.L., Sumner, D.Y., Berger, G., Crisp, J.A., Hurowitz, J.A., Anderson, R., Des Marais, D J, Stolper, E.M., Edgett, K.S., Gupta, S., and Spanovich, N. (2014) Mineralogy of a mudstone at Yellowknife Bay, Gale crater, Mars. Science (New York) 343:1243480.

van Zuilen, M. (2008) Stable isotope ratios as a biomarker on Mars. Space Sci Rev 135:221-232.

Waldo, G.S., Carlson, R.M., Moldowan, J., Peters, K.E., and Penner-Hahn, J.E. (1991) Sulfur speciation in heavy petroleums: information from X-ray absorption near-edge structure. Geochim Cosmochim Acta 55:801-814.

Wang, R. and Fu, J. (1997) Variability in biomarkers of different saline basins in China. Int J Salt Lake Res 6:25-53.

Wawrzynkiewicz, W. and Sablik, J. (2002) Organic sulphur in the hard coal of the stratigraphic layers of the Upper Silesian coal basin. Fuel 81:1889-1895.

Yang, G.-P., Liu, X.-L., and Zhang, J.-W. (1998) Distribution of dibenzothiophene in the sediments of the South China Sea. Environ Pollut 101:405-414.

Zhou, D. and White, R.H. (1989) Biosynthesis of caldariellaquinone in Sulfolobus spp. J Bacteriol 171:6610-6616.

Address correspondence to: Dirk Schulze-Makuch Center for Astronomy and Astrophysics (ZAA) Astrobiology Research Group Technische Universität Berlin Hardenbergstr. 36 Berlin 10623 Germany

E-mail: schulze-makuch@tu-berlin.de

Submitted 12 July 2019

Accepted 24 January 2020 Associate Editor: Radu Popa

$\begin{aligned} & \text { Abbreviations Used } \\ \mathrm{BDTQ} & =\text { benzodithiopheno-quinone } \\ \mathrm{BK} & =\text { Buckskin } \\ \mathrm{BSR} & =\text { bacterial sulfate reduction } \\ \mathrm{CB} & =\text { Cumberland } \\ \mathrm{CH} & =\text { Confidence Hills } \\ \mathrm{CQ} & =\text { Caldariellaquinone } \\ \mathrm{EGA} & =\text { evolved gas analysis } \\ \mathrm{GC}-\mathrm{MS} & =\text { gas chromatography-mass spectrometry } \\ \mathrm{JK} & =\text { John Klein } \\ \mathrm{MJ} & =\text { Mojave } 2 \\ \mathrm{TP} & =\text { Telegraph Peak }\end{aligned}$

